\title{
Peran Ibu Terhadlap Durasi Diare Akut Anak Umur 6-24 Bulan Selama Perawatan
}

\author{
G.Panji Pati Pati, Ninung Rose DK, I.Hartantyo, Ag.Soemantri \\ Departemen Ilmu Kesehatan Anak RSUP Dr. Kariadi Fakultas Kedokteran Universitas Diponegoro, \\ Semarang
}

Latar belakang. Peran ibu (knowledge, attitude, practise) dalam menurunkan durasi diare akut anak selama perawatan sangat penting. Oleh karena itu, diperlukan pemerataan dan peningkatan upaya pencegahan, pemberantasan, dan tatalaksana diare anak sehingga peran ibu diharapkan dapat menurunkan durasi diare.

Tujuan. Membuktikan hubungan antara peran ibu dengan durasi diare akut anak selama perawatan di RSUP dr. Kariadi, Semarang.

Metode. Rancangan studi potong lintang dengan subjek ibu dan anaknya yang berumur 6-24 bulan yang dirawat di Bangsal Gastroenterohepatologi RSUP Dr. Kariadi, Semarang karena diare akut pada bulan Mei-Agustus 2011. Penilaian peran ibu (knowledge, attitude, practise) dengan wawancara menggunakan kuesioner terpimpin, terdiri atas 15 pertanyaan dengan skor 0-15 untuk pengetahuan dan sikap, 0-45 untuk perilaku. Durasi diare adalah lama hari anak mengalami diare selama perawatan. Durasi pendek apabila dirawat selama 1-4 hari dan panjang $>4$ hari. Analisis statistik menggunakan analisis bivariat, untuk uji hipotesis dengan Spearman Rho Correlation Test.

Hasil. Didapatkan 35 subjek selama periode penelitian. Korelasi skor total pengetahuan ibu terhadap durasi pendek selama perawatan diare didapatkan korelasi positif $(0,169)$, sikap ibu didapatkan korelasi positif $(0,220)$, praktek ibu didapatkan korelasi positif $(0,012)$. Ketiganya dengan kekuatan korelasi lemah, dan untuk korelasi skor total KAP (knowledge, attitude, practise) ibu terhadap durasi pendek didapatkan korelasi positif $(0,157)$ dengan kekuatan korelasi lemah.

Kesimpulan. Tidak terdapat hubungan antara peran ibu dengan durasi diare akut anak selama perawatan. Sari Pediatri 2013;15(1):56-60.

Kata kunci: peran ibu (knowledge, attitude, practise), durasi diare akut

\section{Alamat korespondensi:}

Dr. G.Panji Pati Pati. Departemen Ilmu Kesehatan Anak RSUP dr. Kariadi Semarang Jl. dr. Soetomo 18 Semarang. E-mail: panjipatipati@ yahoo.com

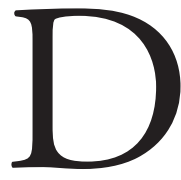

iare masih merupakan penyebab kesakitan dan kematian utama pada anak di negara berkembang. Tahun 2003 diperkirakan

1,87 juta anak di bawah 5 tahun meninggal karena diare dan angka kesakitan diare meningkat menjadi 374 per 1.000 penduduk dan episode pada balita 1,08 kali per tahun. ${ }^{1}$ 
Hasil survei kesehatan rumah tangga (SKRT) di Indonesia tahun 1995 ditunjukkan angka kematian diare balita 1 per mil per tahun dan bayi 8 per mil per tahun. Episode diare terbanyak terjadi 2 tahun pertama kehidupan dengan insiden tertinggi pada golongan umur 6-11 bulan. ${ }^{1,2}$ Di Indonesia, angka kejadian diare 60 juta/ tahun, menyebabkan kematian 300.000-500.000 tiap tahunnya. Angka kesakitan dan kematian yang tinggi akibat diare menjadikan usaha penanggulangannya sangat penting. Pengelolaan diare yang benar dapat mengurangi lebih dari 95\% kematian akibat diare. ${ }^{2}$

Penyebab diare bersifat multifaktorial, masalah sanitasi, perilaku manusia yang memanfaatkan sarana sanitasi, keadaan gizi, sosial ekonomi, dan budaya sangatlah berpengaruh dan berkaitan. Hubungan interaktif antara proses diare dan malnutrisi yang bersifat sinergestis disebut interaksi diare-malnutrisi. Oleh karena itu, maka orang tua berperan sangat penting dalam hal pengelolaan diare akut anak. ${ }^{3}$

Faktor-faktor yang saling berinteraksi dan mempengaruhi pertumbuhan anak, di antaranya meliputi kondisi lingkungan (proximal environment), tingkat kematangan (maturation stage), kepekaan biologik (biological vulnerability). Secara teoritik ketiga faktor tersebut dapat diamati dari keadaan fisik perumahan, pendapatan keluarga, perilaku sosial keluarga, umur (Chronological age), kandungan zat besi (penting untuk kejadian infeksi ), dan kejadian sakit (lebih-lebih) diare.

Peran orang tua (ibu) dalam hal ini, merupakan suatu perilaku yang juga memanfaatkan sarana sanitasi, keadaan gizi, sosial ekonomi, dan budaya yang sangat berpengaruh dan berkaitan terjadinya diare. Perilaku adalah suatu tindakan atau perbuatan dari organisme yang dapat diamati dan bahkan dipelajari. Di dalam proses pembentukan dan atau perubahan, perilaku dipengaruhi oleh beberapa faktor yang berasal dari dalam dan dari luar individu sendiri. ${ }^{4,5}$

Perilaku seseorang terdiri dari tiga bagian, yaitu kognitif, afektif, dan psikomotor. Kognitif diukur dari pengetahuan (knowledge), afektif dari sikap (attitude) atau tanggapan, dan psikomotor diukur melalui praktik/tindakan (practice). Pembentukan dan perubahan perilaku dipengaruhi beberapa faktor yang berasal dari dalam dan luar individu. Faktor dari dalam mencakup pengetahuan, kecerdasan, persepsi, sikap emosi dan motivasi yang berfungsi mengolah rangsang dari luar. Faktor dari luar meliputi lingkungan sekitar baik fisik maupun non fisik seperti iklim, sosial, ekonomi, budaya, dan sebagainya.
Peran ibu (knowledge, attitude, practice) dalam menurunkan durasi diare akut anak selama perawatan sangat penting. Oleh karena itu, suatu pemahaman yang benar tentang penyakit diare sangat diperlukan untuk para orang tua. Masyarakat perlu diberdayakan melalui paguyuban dan organisasi kemasyarakatan, seperti kelompok dasa wisma, kegiatan Posyandu, kelompok arisan, kelompok kegiatan keagamaan dan sebagainya. Kebijakan pemerintah dalam upaya penanggulangan diare adalah menurunkan angka kesakitan, angka kematian dan penanggulangan kejadian luar biasa diare dengan melibatkan semua pihak, lintas program, lintas sektoral dan masyarakat secara umum, terutama orang tua. Pemerataan dan peningkatan upaya-upaya tersebut di atas diharapkan peran ibu (knowledge, attitude, practice) dapat menurunkan durasi diare akut pada anak selama perawatan. ${ }^{3}$ Tujuan penulisan untuk menyampaikan hasil penelitian tentang hubungan antara peran ibu dengan durasi diare akut pada anak.

\section{Metode}

Jenis dan rancangan penelitian potong lintang, dilakukan bulan Mei-Agustus 2011 di Bangsal Gastroenterohepatologi RSUP. Dr. Kariadi, Semarang. Populasi target adalah ibu dengan anaknya yang menderita diare akut, sedangkan untuk populasi terjangkau adalah ibu dengan anaknya yang menderita diare akut dan dirawat di Bangsal Rawat Inap Gastroenterohepatologi Anak RSUP. Dr.Kariadi, Semarang. Sampel penelitian adalah ibu dengan anaknya yang berumur 6-24 bulan dengan diare akut yang memenuhi kriteria inklusi. Subjek dipilih dengan metode consecutive sampling. Subjek yang memenuhi kriteria penelitian akan digunakan sebagai sampel dan dilakukan wawancara dengan kuesioner terpimpin. Pengambilan sampel akan dihentikan setelah jumlah sampel minimal terpenuhi. Dari perhitungan sampel minimal dibutuhkan 33 subjek. Variabel bebas adalah peran ibu (knowledge, attitude, practice),yang diukur dengan kuesioner terpimpin, terdiri atas 15 pertanyaan dengan skor antara 0-15 untuk pengetahuan dan sikap, skor 0-45 untuk perilaku. Variabel tergantung adalah durasi diare akut anak selama perawatan yang dinilai dalam hari, disebut durasi pendek apabila anak dirawat selama 1-4 hari dan durasi panjang apabila anak dirawat $>4$ hari. Variabel pengganggu adalah masukan makanan pada anak. Analisis statistik menggunakan analisis bivariat, untuk uji hipotesis peran 
ibu dengan durasi diare akut anak selama perawatan dianalisis dengan Spearman rho correlation test.

\section{Hasil}

Selama periode penelitian dijumpai 35 ibu dengan anaknya berumur 6-24 bulan dengan diare akut yang dirawat di Bangsal rawat inap Gastroenterohepatologi RSUP.Dr. Kariadi, Semarang yang memenuhi kriteria penelitian. Karakteristik subjek penelitian tertera pada Tabel 1.

Data deskriptif rerata dan median variabel yang

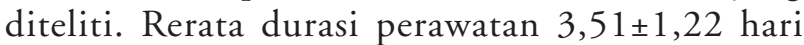
dengan perawatan minimal 1 hari dan maksimal 6 hari. Skor total pengetahuan didapatkan rerata $11,9 \pm 1,00$, dengan skor minimal 10 dan maksimal 14 . Skor total sikap didapatkan rerata $11,7 \pm 1,19$, dengan skor minimal 10 dan maksimal 14 . Skor total praktek didapatkan rerata $35,9 \pm 3,94$, dengan skor minimal 19 dan maksimal 42. Skor total KAP (knowledge, attitude, practise) didapatkan rerata 59,4 44,5 dengan skor minimal 43 dan maksimal 67.

Peran ibu dalam pengetahuan (skor total 294), sikap (skor total 289), praktek (skor total 1112) dan KAP (skor total 1695) mempunyai durasi perawatan yang pendek sedangkan pengetahuan (skor total 36), sikap (skor total 38), praktek (skor total 148), dan KAP (skor total 222) mempunyai durasi perawatan yang panjang.

Analisis korelasi antara skor total pengetahuan, sikap, praktek, dan KAP (knowledge, attitude, practise) terhadap durasi pendek selama perawatan tertera pada Tabel 4. Korelasi skor total pengetahuan ibu terhadap durasi pendek selama perawatan diare didapatkan korelasi positif $(0,169)$ dengan kekuatan korelasi lemah. Korelasi skor total sikap ibu terhadap durasi pendek selama perawatan diare didapatkan korelasi positif $(0,220)$ dengan kekuatan korelasi lemah. Korelasi skor total praktek ibu terhadap durasi pendek selama perawatan diare didapatkan korelasi positif $(0,012)$
Tabel 1. Karakteristik subjek $(\mathrm{n}=35)$ y

\begin{tabular}{|c|c|c|}
\hline Karakteristik & $\mathrm{n}(\%)$ & Rerata \pm SB \\
\hline \multicolumn{3}{|l|}{ Jenis kelamin anak } \\
\hline Laki-laki & $20(57,1)$ & - \\
\hline Perempuan & $15(42,9)$ & - \\
\hline Umur anak (bulan) & - & $10,1 \pm 4,18$ \\
\hline \multicolumn{3}{|l|}{ Status imunisasi } \\
\hline Lengkap & $34(97,1)$ & - \\
\hline Tidak lengkap & $1(2,9)$ & - \\
\hline Umur ayah (tahun) & $29,3 \pm 5,36$ & \\
\hline \multicolumn{3}{|l|}{ Pendidikan ayah } \\
\hline SD & $1(2,9)$ & - \\
\hline SMP & $6(17,1)$ & - \\
\hline SMA/SMK/STM & $28(80,0)$ & - \\
\hline \multicolumn{3}{|l|}{ Pekerjaan ayah } \\
\hline Pegawai & $18(51,4)$ & - \\
\hline Buruh/buruh tani & $6(17,1)$ & - \\
\hline Petani & $3(8,6)$ & - \\
\hline Montir & $2(5,7)$ & - \\
\hline Supir & $2(5,7)$ & - \\
\hline Petugas keamanan & $2(5,7)$ & - \\
\hline Wiraswasta & $1(2,9)$ & - \\
\hline Tidak bekerja & $1(2,9)$ & - \\
\hline Umur ibu (tahun) & - & $26,7 \pm 4,65$ \\
\hline \multicolumn{3}{|l|}{ Pendidikan ibu } \\
\hline SD & $3(8,6)$ & - \\
\hline SMP & $6(17,1)$ & - \\
\hline SMA/SMK/SMEA & $26(74,3)$ & - \\
\hline \multicolumn{3}{|l|}{ Pekerjaan ibu } \\
\hline Ibu rumah tangga & $25(71,4)$ & - \\
\hline Buruh & $1(2,9)$ & - \\
\hline Pegawai & $6(17,1)$ & - \\
\hline Pedagang & $3(8,6)$ & - \\
\hline \multicolumn{3}{|l|}{ Jumlah balita dalam keluarga } \\
\hline 1 & $23(65,7)$ & - \\
\hline 2 & $12(34,3)$ & - \\
\hline Status sosial ekonomi & - & $18,6 \pm 1,91$ \\
\hline Jumlah frekuensi rawat/bln & - & $1,2 \pm 0,66$ \\
\hline Jumlah KRS/bln & - & $1,25 \pm 0,76$ \\
\hline
\end{tabular}

Tabel 2. Rerata dan median variabel yang diteliti

\begin{tabular}{lcccc}
\hline Variabel & Rerata \pm SB & Median & Min & Max \\
\hline Durasi selama perawatan (hari) & $3,51 \pm 1,22$ & 3 & 1 & 6 \\
Skor total pengetahuan/knowledge & $11,9 \pm 1,00$ & 12 & 10 & 14 \\
Skor total sikap / attitude & $11,7 \pm 1,19$ & 11 & 10 & 14 \\
Skor total praktek / practice & $35,9 \pm 3,94$ & 36 & 19 & 42 \\
Skor total KAP & $59,4 \pm 4,50$ & 60 & 43 & 67 \\
\hline
\end{tabular}


G.Panji Pati Pati dkk: Peran ibu terhadap durasi diare akut anak selama perawatan

Tabel 3. Skor total pengetahuan, sikap, praktek, dan KAP terhadap durasi selama perawatan

\begin{tabular}{lcccc}
\hline \multirow{2}{*}{ Durasi perawatan (hari) } & \multicolumn{4}{c}{ Skor total } \\
\cline { 2 - 5 } & Pengetahuan & Sikap & Praktek & KAP \\
\hline Pendek $(1-4)$ & 294 & 289 & 1112 & 1695 \\
Panjang $(>4)$ & 36 & 38 & 148 & 222 \\
\hline
\end{tabular}

Tabel 4. Analisis korelasi antara skor total pengetahuan, sikap, praktek, dan KAP

\begin{tabular}{lcccc}
\hline Deskripsi & \multicolumn{4}{c}{ Skor p (r)* } \\
\cline { 2 - 5 } & Pengetahuan & Sikap & Praktek & Skor KAP \\
\hline Durasi pendek selama perawatan & $0,364(0,169)$ & $0,234(0,220)$ & $0,491(0.012)$ & $0,398(0,157)$ \\
Skor total pengetahuan & -- & $0,000(0,682)$ & $0,444(0,143)$ & $0,001(0,557)$ \\
Skor total sikap & -- & -- & $0,411(0,153)$ & $0,001(0,572)$ \\
Skor total praktek & & -- & -- & $0,000(0.801)$ \\
\hline
\end{tabular}

*Dianalisis dengan Spearman Rho Correlation Test

dengan kekuatan korelasi lemah, sedangkan untuk korelasi skor total KAP (knowledge, attitude, practise) ibu terhadap durasi pendek selama perawatan diare didapatkan korelasi positif $(0,157)$ dengan kekuatan korelasi lemah. Korelasi skor total pengetahuan dengan skor total sikap pada ibu didapatkan korelasi positif $(0,682)$ dengan kekuatan korelasi kuat. Korelasi skor total pengetahuan dengan skor total praktek pada ibu didapatkan korelasi positif $(0,143)$ dengan kekuatan korelasi lemah. Korelasi skor total pengetahuan dengan skor total KAP pada ibu didapatkan korelasi positif $(0,557)$ dengan kekuatan korelasi kuat.

\section{Pembahasan}

Pada penelitian kami, upaya menilai peran ibu terhadap durasi diare akut pada anak umur 6-24 bulan selama perawatan dengan menggunakan kuesioner terpimpin, meliputi upaya kegiatan pencegahan diare berupa pemberian ASI yang benar, memperbaiki makanan pendamping ASI, penggunaan air bersih yang cukup, membudayakan kebiasaan mencuci tangan dengan sabun sehabis buang air besar dan sebelum menjamah makanan dan minuman, penggunaan jamban yang saniter oleh seluruh anggota keluarga, membuang tinja yang benar dan pemberian imunisasi campak. Upaya tatalaksana pasien diare dilakukan baik pada institusi kesehatan, seperti rumah sakit dan puskesmas maupun di luar institusi kesehatan, yaitu di rumah. Prinsip tatalaksana diare adalah dengan mencegah terjadinya dehidrasi, mengobati dehidrasi, dan tetap memberikan makanan. ${ }^{6}$
Menurut penelitian Datta $\mathrm{dkk}^{7}$ di India, didapatkan hasil ibu mencampur ORS (oral rehidration solution) dengan cara yang salah, hampir $50 \%$ ibu tidak mempraktekkan cuci tangan secara adekuat, 32\% menggunakan botol dot 2/3 nya tidak direbus dahulu.

Menurut penelitian Cuevaz $\mathrm{dkk}^{8}$ di Mexico, didapatkan hasil ibu menghentikan diare pada anak dengan menggunakan teh herbal 52,3\%, cairan pencegah dehidrasi $92,2 \%$, obat $35,2 \%$, merubah bentuk makanan 36,3\%, mengurangi susu 12,2\%.

Menurut penelitian Vanderlei, ${ }^{9}$ didapatkan hasil terdapat hubungan secara statistik antara pasien yang dirawat dengan diare akut dengan kondisi sosial ekonomi; malnutrisi; mendapatkan ASI dalam waktu singkat; kurangnya pengetahuan ibu tentang bagaimana menghindari dehidrasi dan penggunaan $O R S$ secara efektif. Tidak terdapat hubungan secara statistik pada pengetahuan ibu tentang tanda dehidrasi dan manajemen dari diare akut pada anak.

Menurut penelitian Jha $\mathrm{dkk}^{10}$ di Sunsari Nepal, didapatkan hasil mayoritas ibu mendapatkan informasi tentang $O R S$ yang sangat berguna untuk manajemen dehidrasi yang disebabkan karena diare. Limapuluh persen ibu dapat membuat dan memberikan ORS pada anaknya secara ideal (setelah tiap kali mencret). Penggunaan ORS dapat menurunkan mortalitas karena dehidrasi, dan efeknya dapat terlihat dengan jelas dalam waktu singkat. Intervensi seperti memperbaiki sanitasi dasar, pelayanan kesehatan, dan tercapainya status nutrisi secara umum dari populasi hanya dapat tercapai dengan menurunkan morbiditas dan mortalitas karena penyakit diare dalam jangka waktu lama. 
Menurut penelitian Ranjabar ${ }^{11}$ di Iran, didapatkan hasil pada anak diare $84,2 \%$ mendapatkan ASI, $80 \%$ ibu tidak memberi sup, banyak subyek mendapat lemak (74,5\%), suplemen besi $(91 \%)$, multivitamin (86\%), dan jus buah (88\%).

Berisha $^{12}$ meneliti di Kosova, mendapatkan hasil pada anak dengan diare 60,7\% kurang atau tidak mendapatkan semua cairan, yang biasanya hanya 19,6\% dan lebih dari 17,8\%. Lebih dari 1/3 ibu tidak memberikan ASI pada bayi kurang dari umumnya, dan $75 \%$ kasus lebih dari umumnya selama diare. Dari tempat tinggal dan umur ibu memberi makanan pada anak diare tidak terdapat perbedaan yang signifikan, tetapi terdapat perbedaan bermakna pada pendidikan ibu. Sepertiga ibu tidak memberikan apaapa pada anaknya untuk menghentikan diare, 19,6\% menggunakan jus beras, $15,9 \%$ pisang, dan hanya 9,3\% yang mendapatkan ORS.

Menurut penelitian Kudlova ${ }^{13}$ di Republik Czech, didapatkan hasil pengetahuan ibu tentang $O R S(27,6 \%)$ dan penggunaan ORS $(1,9 \%$ selama episode terakhir diare pada anak) rendah. Terdapat hubungan yang positif dengan tingkat pendidikan, tetapi tidak dengan sumber asupan. Pamberian ORS dengan jumlah sedikit diisukan sebagai penyebab. Peningkatan pemberian cairan $>60 \%$ anak secara bermakna berhubungan dengan pendidikan ibu yang tinggi dan temannya (76\%) sebagai sumber asupan dibandingkan dengan dokter anak $(57,9 \%)$, sumber asupan yang paling sering didapat $(78,1 \%)$. Teh hitam adalah cairan yang tersering diberikan $(86,2 \%)$, diikuti air mineral $(41,9 \%)$. Pemberian Asi tetap dilanjutkan; hanya 1 kasus diberikan formula rendah laktosa. Makanan tambahan jarang diberikan $(5,2 \%)$, tetapi $75,2 \%$ kasus diberikan makanan modifikasi. Obat-obatan diberikan pada 52,4\% anak, obat tersering diberikan smectite dan atau probiotik, dan pada 6,4\% kasus diberikan antibiotik.

Keterbatasan dari penelitian kami adalah tidak diteliti dengan membedakan penyebab diare pada anak, apakah penyebab infeksi (bakteri, virus atau jamur) maupun non infeksi.

\section{Kesimpulan}

Tidak terdapat hubungan antara peran ibu dengan durasi diare akut anak selama perawatan. Disarankan penelitian lebih lanjut dengan sampel yang lebih besar untuk menilai peran ibu terhadap durasi diare akut dan penyebab diare pada anak umur 6-24 bulan. Penelitian dengan wawancara menggunakan kuesioner terpimpin yang sudah dikembangkan lagi dengan validitas internal dan eksternal atau sudah disetujui dalam konsensus ahli.

\section{Daftar pustaka}

1. Ditjen PPM dan PLP Departemen Kesehatan RI. Buku ajar diare. Jakarta: Departemen Kesehatan RI; 1999.h.314.

2. Widaya IW, Gandi. Konsistensi pelaksanaan program serta morbiditas dan mortalitas diare di era otonomi dan krisis. Dalam: Kongres Nasional II BKGAI. Bandung: BKGAI; 2003.h.45-54.

3. Sudigbia I. Pengaruh suplementasi tempe terhadap kecepatan tumbuh pada penderita diare anak umur 6-24 bulan (disertasi). Universitas Diponegoro, 1990.

4. Notoatmodjo S. Ilmu kesehatan masyarakat. Jakarta: Rineka Cipta, 1997.

5. Notoatmodjo S. Pendidikan dan perilaku kesehatan. Jakarta: Rineka Cipta, 2003.

6. Kandun IN. Upaya pencegahan diare ditinjau dari aspek kesehatan masyarakat. Dalam: Kongres Nasional II BKGAI. Bandung: BKGAI; 2003: 29-43.

7. Datta V, John R, Singh VP, Chaturvedi P. Maternal kowledge, attitude and practices towards diarrhea and oral rehydration therapy in rural Maharashtra. Indian J Pediatric 2001;68:1035-7.

8. Perez-cuevaz R, Guiscafre H, Romero G, Rodriguez L, Gutierrez. Mothers health seeking diarrhoea in Tlaxcala, Mexico. J Diarrhoeal Dis Res 2000;14:260-8.

9. Vanderlei LC, Silva GA. Acute diarrhea:does mother knowledge of the disease reduce admission of children under two years of age? 2004;50:276-81.

10. Jha N, Singh R, Barat D. Knowledge, attitude and practise of mother regarding home management of acute diarrhoea in Sunsari, Nepal. Nepal Med Coll J 2006;8:27-30.

11. Ranjabar S, Bavafa B. Iranian mothers child feeding practises during diarrhea: A study in Kerman. Pakistan J Nutr 2007;6:217-9.

12. Berisha. Maternal practise on management of acute diarrhea among children under five years old in Kosova. J TAF Prevent Med Bull 2009;8:369-72.

13. Kudlova E. Home management of acute diarrhoea in Czech children. J Pediatr Gastroenterol Nutr 2010; 50:510-5. 